\title{
Building on the evidence: Interventions promoting NCLEX
} success

\author{
Judy R. Hyland \\ Pearson Education, Upper Saddle River, USA \\ Email: judy.hyland@pearson.com
}

Received 25 April 2012; revised 25 May 2012; accepted 1 June 2012

\begin{abstract}
Nurse educators have implemented a variety of teaching/learning interventions in an effort to maintain or improve student success and NCLEX pass rates. An integrative review of literature from 2004 through 2010 was conducted to investigate the specific strategies used and their outcome effectiveness. Five major databases were queried using the search terms of test taking, preparation, remediation, success, review course, HESI, Pearson, Kaplan, ATI, Hurst and NCLEX. Of the resultant 40 articles, 14 met the inclusion criteria and provided measurable outcomes. All studies implemented multiple strategies at a single institution; 7 included standardized testing and 7 used review courses as one of the multiple intervenetions. When standardized testing was a strategy included with individual and curricular changes, NCLEX passage improvement was found for 6 schools. Review courses coupled with individual and cohort interventions improved success in 5 of 7 schools. This review discusses commonalities and differences of a combination of teaching/learning interventions that improved NCLEX success.
\end{abstract}

Keywords: NCLEX; Remediation; Review Course; Standardized Examination

\section{INTRODUCTION}

Over the past twenty-five years, nurse educators have implemented a variety of interventions to increase Registered nurse licensure pass rates and have looked for ways to predict student success on this high stakes examination. Educational science is needed to make evidencebased decisions about teaching methods that promote success of NCLEX-RN ${ }^{\circledR}$. The aim of this integrated review was to describe the state of $\mathrm{RN}$ licensure remediation science. Specifically, this report will describe teaching/learning strategies and outcomes used to aide RN licensure success.

\section{METHODS}

\subsection{Databases and Search Terms}

Burns (2008) defines an integrative review of the literature as one that identifies, analyzes, and synthesizes research findings from both quantitative and qualitative studies to determine the current knowledge [1]. The $\mathrm{Cu}-$ mulative Index to Nursing and Allied Health Literature (CINAHL), ProQuest, PubMed, and the Educational Resources Information Center (ERIC) databases were searched for the years of 2004 through May 2011. The terms remediation, test taking, success, preparation, review course, Pearson, Kaplan, ATI, Hurst and HESI, were each paired with the term NCLEX, and a total of 269 articles from peer-reviewed journals were found (Table 1).

\subsection{Study Criteria}

Reports on remediation concepts, research studies, and program evaluations to improve nursing student NCLEX$\mathrm{RN}^{\circledR}$ success from Bachelor of Science in Nursing (BSN), Associate Degree in Nursing (ADN), and Diploma programs were included. After duplicate and reprinted articles with initial publication dates prior to 2004 were removed the total was reduced to 56 publications. The complete compilation of evidence revealed one concept analysis on remediation, three models, and two literature reviews. The remaining publications, were descriptive interventional reports $(\mathrm{n}=14)$ and research reports $(\mathrm{n}=$ $36)$. Of the 36 research reports, fourteen (14) publications were reports of interventional studies. Specific category details are displayed in Figure 1.

\section{FINDINGS}

\subsection{Conceptual Frameworks}

McDowell in 2008 presented the KATTs framework and explained how KATT has been used successfully in designing remedial tutoring programs for NCLEX-RN ${ }^{\circledR}$ preparation [2]. The KATTS framework centers on three 
Table 1. Terms and number of articles retrieved when the search terms were combined with NCLEX.

\begin{tabular}{cc}
\hline Search Terms & Number of Articles \\
\hline Remediation & 39 \\
Test Taking & 48 \\
Success & 111 \\
Preparation & 13 \\
Review Course & 1 \\
HESI, Pearson, Kaplan, ATI and Hurst Combined & 56 \\
Total & 269 \\
\hline
\end{tabular}

components for improving test scores, an adequate knowledge base, active anxiety control, and effective test-taking skills [2]. In 2000 the pass rate was $85 \%$ and the mean pass rate between 2001-2006 increased to $97 \%$, during the last two years the rate reached $100 \%$ [2]. Greenspan (2009) reported on a conceptual model to better understand NCLEX-RN ${ }^{\circledR}$ success [3]. The as- sumption in Tri-Nodal Model is that accountability for NCLEX success relies on students, faculty, and employers, working together [3]. Sitzman (2007) proposed that a double-loop theoretical approach is needed to address culturally competent interventions [4]. The double-loop approach encompasses interventions in both elementary and secondary schools, student support services, faculty development, evaluations, research, and evidence-based interventions are proposed to address the special needs of diverse students [4]. In summary, these three reports provided a framework for improving NCLEX outcomes by focusing on the knowledge building, reducing anxiety, and developing test taking strategies when developing remedial programs. The models include not just the student, but also the faculty and employers in sharing the responsibility for NCLEX success.

\subsection{Concept Analysis}

In 2009, Culleiton reported that the concept of remediation remained unclear within the context of nursing education. The definition of remediation was expanded to

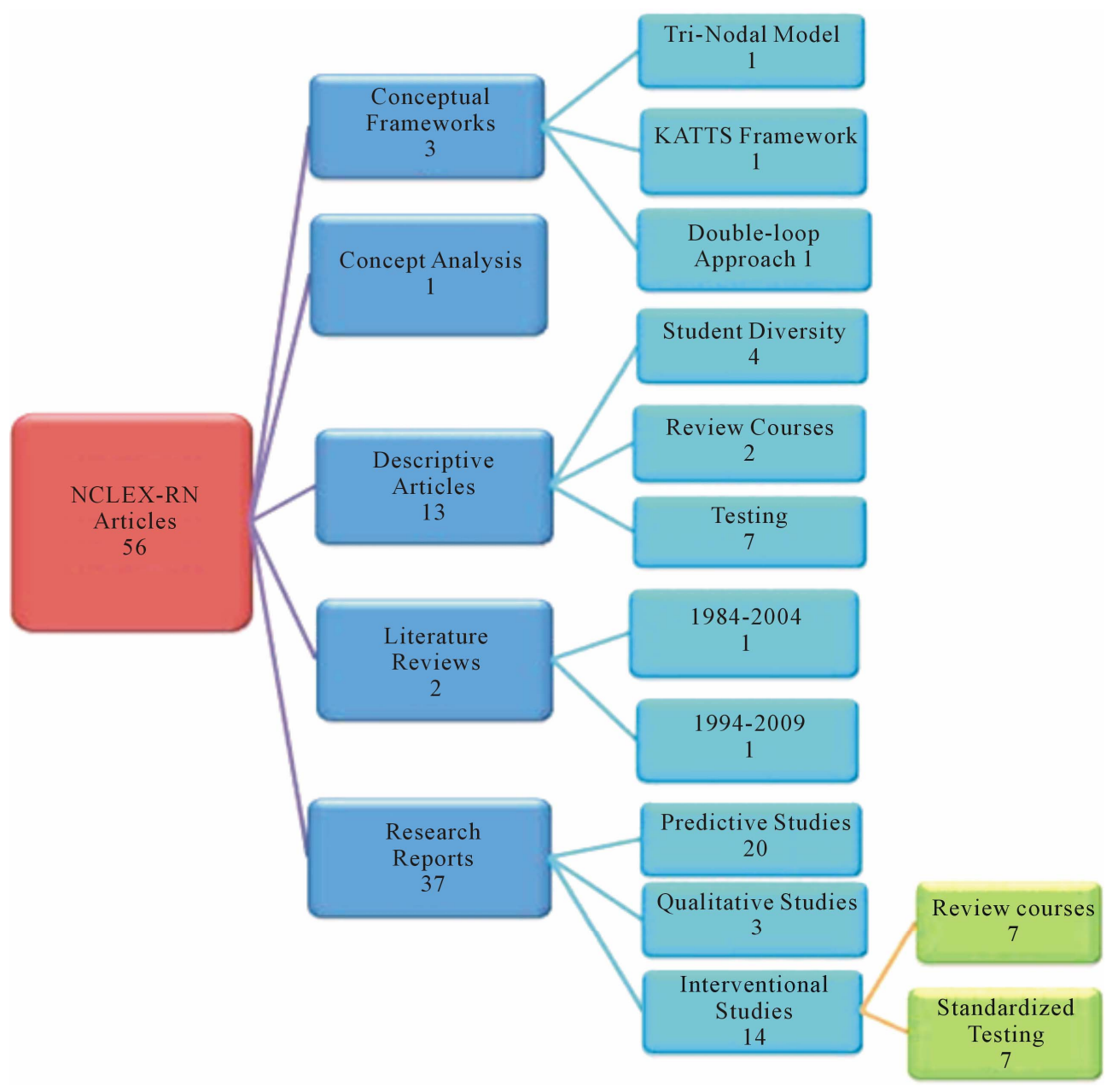

Figure 1. Search results and categories of articles. 
"the process of identifying the need to take action to remedy a situation that, if left unresolved, will result in unfavorable outcomes, whereas implementing intervenetion strategies will successfully address the situation" [5]. One important insight from Culleiton's work is, in order to have successful remediation; the process must begin early in the student's program and not relegated to last semester/quarter remediation [5].

\subsection{Descriptive Studies}

Of the 13 descriptive reports retrieved only one study was a multi-site investigation. These reports addressed student diversity issues, the use of testing within the curriculum, and review as a method to increase NCLEX$\mathrm{RN} \circledast$ pass rates.

\subsection{Student Diversity}

In 2004, Cunningham, Stacciarini and Towle presented interventions to improve language proficiency for English-as-a-Second-Language (ESL) nursing students [6]. The authors indicated that some of these strategies may be helpful for more than one issue related to ESL students [6]. An approach to increase first-time pass rate for Hispanic students was presented by Stewart in 2008 [7]. Culturally sensitive modules were implemented. Students participating in the program were awarded a stipend. After implementation, NCLEX first-time pass rates increased from $70 \%$ to $90 \%$ over the course of two years [7]. In 2004, McQueen at a historically Black college adopted a collective community approach to preparing students. Faculty advisors were assigned to students and assisted students with academic and psychosocial issues [8]. Family "groups" were formed to support each other [8]. Cramer and Davidhizar (2008) initially met cultureally diverse student needs by individual counseling, but after 2 years, the methodology was replaced by a study and test taking skills, computer skills, stress management, problem solving and critical thinking skills course [9]. A second course was developed to help students apply critical thinking to clinical problem solving. Post-program NCLEX-RN ${ }^{\circledR}$ pass rates increased, although no numerical data was provided [9].

\subsection{Review Courses}

Herrman and Johnson (2009) presented the use of a residency curriculum [10]. This new curriculum had two seminars during the final year. The first seminar includeing information on culturally competent care, health care practices, legal issues, and career planning. The second seminar formalized NCLEX-RN ${ }^{\circledR}$ preparation efforts. Herrman and Johnson (2009) indicated that these seminars enhanced NCLEX-RN ${ }^{\circledR}$ success [10]. In 2010,
Poorman, Mastorovich, Liberto, and Gerwick instituted a 3-credit cognitive behavioral course for at-risk senior nursing students [11]. Self assessment, test questions, test-taking strategies, test anxiety issues, and individualized study plans were included. The student participants had an overall pass rate of $92 \%$. In the next year the overall pass rate was $100 \%$ [11].

\subsection{Testing}

In seven publications, standardized testing was presented along with use of progression policies to improve NCLEX-RN ${ }^{\circledR}$ pass rates. In 2005, Sayles and Shelton reported on the use of a standardized admission assessment as well as students' learning preferences [12]. Another element to success was the development of the learner action plans that began on admission [12]. In 2007, Davenport described an effort to prepare for success that was incorporated standardized testing and remediation in each semester of the program [13]. The program includes critical thinking entrance, a learning style inventory, content specific examinations, and a comprehensive predictor exam [13]. The successful adoption of progression policies was the topic of a publication by Sewell, Culpa-Bondal and Colvin (2008) [14]. Strategies were implementation which included the use of a standardized comprehensive exit examination. As a result, $85 \%$ of the students passed the exit examination with a grade of 900 or better [14]. Jones and Bremner (2008) provide a step by step approach in adopting a comprehensive testing and review program [15]. This process is an overview of critical elements. The steps involved establishing benchmarks, developing remediation plan and motivating students [15]. Holstein, Zangrilli, and Taboas discussed commercially available testing and remediation programs available for used in 2006 with the focus on the 3 most commonly used standardized, norm-referenced testing programs at that time that included; the Educational Resources, Inc. (ERI), Health Educational Systems, Inc (HESI), and Assessment Technologies Institute (ATI) [16]. The authors also presented the adoption process of ATI testing package. They explained that data was being collected to evaluate the effectiveness of the program [16]. Richards and Stone (2008), reported on a study after the adoption of a comprehensive, standardized testing package [17]. This study sought to determine student satisfaction regarding such testing [17]. The students were given a list of six possible barriers. The most frequent barrier to testing was found to be the cost of the program $(n=60)$. First-time pass rates increased from 93 percent and 97 percent a year later [17]. In 2007, Anderson reviewed the process of implementing a program of individualized student advisement at a community college setting after giving a comprehensive 
exit examination, which was found to be successful [18].

\subsection{Reviews}

Two literature reviews both reported on the lack of intervention effectiveness evidence for NCLEX-RN ${ }^{\circledR}$ success. DiBartolo and Seldomridge's (2005) review focused on interventional studies involving baccalaureate-prepared, first-degree nursing students published from 1984 through 2003 [19]. Pennington and Spurlock (2010) reported on eight remediation interventions to improve NCLEX-RN ${ }^{\circledR}$ pass rates, from 1994 through 2009, in their review [20]. While these integrative reviews clarify the science of remediation there are some gaps which are addressed by this review. Principally, the years from 2004 through 2010 are included and the search term for remediation was paired with NCLEX, along with other terms to capture interventions not labeled as remediation strategies. Revealing review courses and standardized testing as the most frequently used interventions to improvements in NCLEX-RN ${ }^{\circledR}$ success.

\subsection{Research Reports}

Of the thirty-six research articles, nineteen reported on predictability. There were three were qualitative studies, and fourteen interventional studies.

\subsection{Predictive Studies}

The use of scores from standardized commercially available examinations were reported most often to predict student success [21-30]. These tests ranged from admission testing to mid-curricular examinations and comprehensive exit examinations [21-28,30]. Cumulative nursing course grades as well as demographic data were used in combination with test scores to predict success. The HESI $^{\mathrm{TM}}$ examinations were shown to be accurate predicttors of success in several studies [22,25,26]. Benchmarking was discussed as an important part of testing. Test scores were used to identify at-risk students [25]. Findings from the study suggest that subtle differences in test scores could be used to identify students at-risk for failing the NCLEX-RN ${ }^{\circledR}$ [24]. There was one report of findings that did not support predictive accuracy of the HESI.

During the same time frame, five researchers reported on the predictive accuracy of HESI examinations. In a study by Gilmore (2008) nursing GPA was the only independent predictor of NCLEX success in that study [24]. Uyehara (2007) found when all variables are analyzed; the scores on the NLN Adult Health Comprehensive Test were significant predictors $(p<0.0001)$ [27]. Critical thinking as a predictor had mixed findings. Shirrell (2008) found that the critical thinking scores were not predictive of NCLEX success [31]. While Giddens (2005) investigated the relationship of critical thinking to performance on the NCLEX, students who passed and failed NCLEXRN® had similar critical thinking dispositions [32]. There was no relationship between change in critical thinking skills and NCLEX-RN® performance. Hence, critical thinking may be useful for predicting individuals who are likely to pass NCLEX-RN®, but are not reliable predictors of those who are likely to fail. Three researchers reported on the use of program requirements and strategies to improve NCLEX success. Crow, 2004 found that standardized admission examinations and contentarea examinations accurately assess readiness for NCLEX [33]. Higgins (2005) reported on a relationship found between one biology course, the science component of the preadmission test, the HESI Exit Examination score, and the nursing skills course to passing the NCLEX [34]. Woo (2009) investigated the effect of lag time on NCLEX score results and found that there was an inverse relationship [35]. Spurlock warned schools not to rely on one predictor alone when making decisions related to students progression throughout the program [23].

\subsection{Qualitative Studies}

Three qualitative studies reported on the lived experience of NCLEX-RN ${ }^{\circledR}$ failure [36], another explored the factors that contribute to success [37]. The third study used a phenomenological method to elicit the perceptions of Korean nurses' preparation for and taking of the NCLEX$\mathrm{RN}^{\circledR}$ [38].

\subsection{Interventional Studies}

Fourteen articles reported on the investigations conducted to measure the effectiveness of interventions to improve NCLEX-RN ${ }^{\circledR}$ success of nursing students. The effects of the interventions with BSN students $(n=11)$, ADN $(n=2)$, and one study looked at foreign nurses preparing for the NCLEX-RN®.

Half of the articles reported on the use of testing as an intervention for NCLEX-RN ${ }^{\circledR}$ success in combination with other strategies [39-45] (Table 2). The remaining seven interventional studies investigated review courses to improve licensing pass rates [46-50] (Table 3).

\subsection{Standardized Testing Interventional Studies}

The authors investigating the use of standardized examinations as interventions for NCLEX-RN ${ }^{\circledR}$ success presented findings with other strategies used in combination with examinations. A reduction of the number of semesters in a curriculum, along with standardized testing was implemented in one nursing program [39]. The 
Table 2. Interventional studies using standardized testing as an intervention.

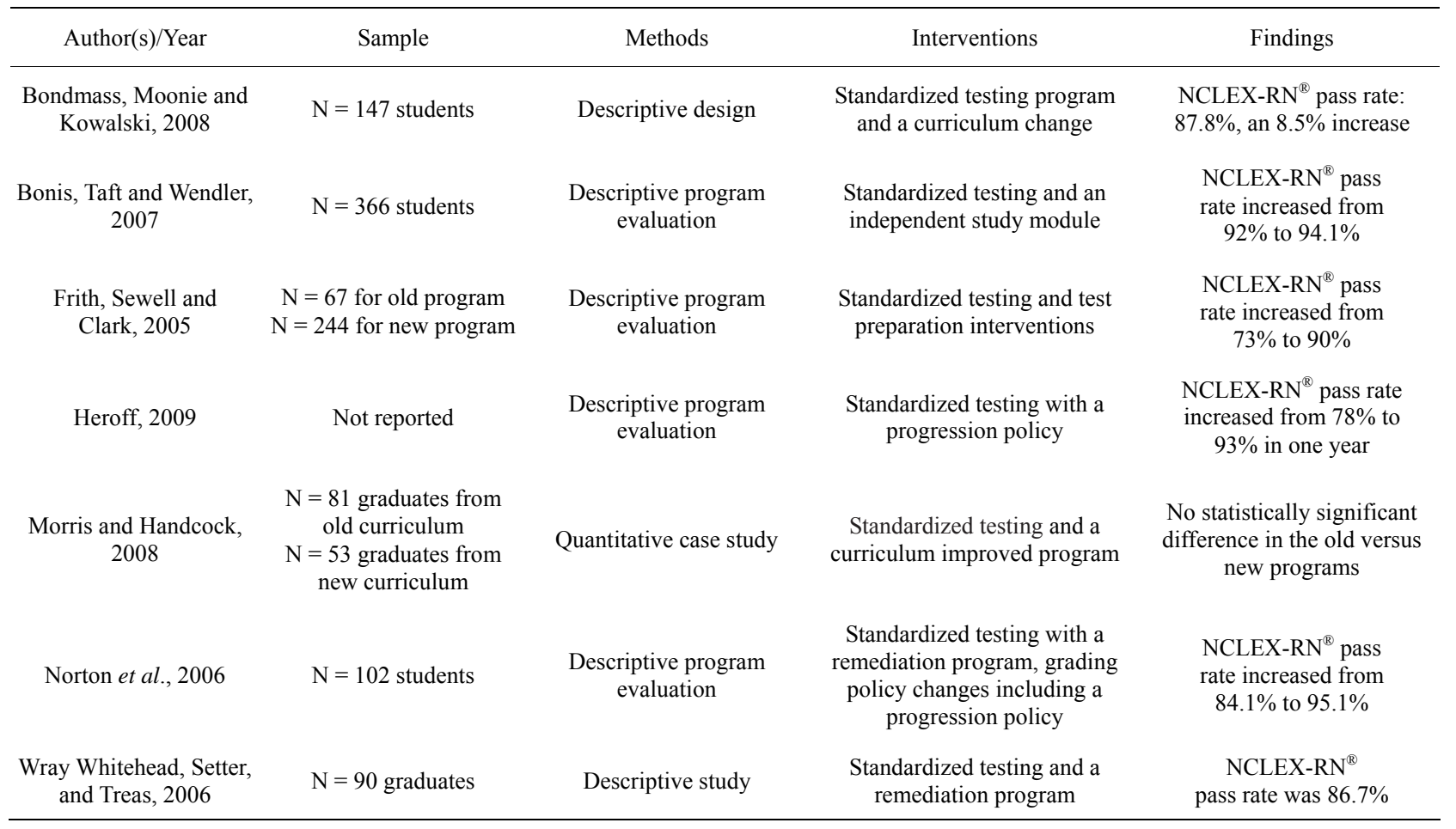

Table 3. Interventional studies using a review course as an intervention.

\begin{tabular}{|c|c|c|c|c|}
\hline Authors/Year & Sample & Methods & Interventions & Findings \\
\hline Lyons, 2008 & $\mathrm{~N}=54$ students & $\begin{array}{l}\text { Experimental pre-post } \\
\text { treatment comparative } \\
\text { design study }\end{array}$ & $\begin{array}{l}\text { Review course control group } \\
\text { received the lecture. Treatment } \\
\text { group received case scenarios. }\end{array}$ & $\begin{array}{l}\text { No significant differences } \\
\text { between methods when critical } \\
\text { thinking was assessed }\end{array}$ \\
\hline $\begin{array}{l}\text { McGann and } \\
\text { Thompson, } 2008\end{array}$ & $\mathrm{~N}=16$ students & $\begin{array}{l}\text { Descriptive mixed } \\
\text { method program } \\
\text { evaluation }\end{array}$ & $\begin{array}{l}\text { Elective course which included } \\
\text { faculty mentoring, journaling, } \\
\text { tutorials, and various self-directed } \\
\text { student activities. }\end{array}$ & $\begin{array}{l}87 \% \text { of the participants } \\
\text { successfully passed the } \\
\text { NCLEX-RN }\end{array}$ \\
\hline Morton, 2006 & $\begin{array}{l}\text { "approximately } 110 \\
\text { students" }\end{array}$ & $\begin{array}{c}\text { Descriptive program } \\
\text { evaluation }\end{array}$ & $\begin{array}{l}\text { NCLEX-RN }^{\circledR} \text { review workshops } \\
\text { with NCLEX-RN }{ }^{\circledR} \text { type questions } \\
\text { throughout the program. }\end{array}$ & $\begin{array}{l}\text { Increase in students' pass rates } \\
\text { from } 65 \% \text { to } 92 \%\end{array}$ \\
\hline Parrone, et al., 2008 & $\mathrm{~N}=67$ foreign nurses & Descriptive study & $\begin{array}{l}\text { A review course and a faculty } \\
\text { mentor, a remediation program, } \\
\text { an early identification program } \\
\text { and a standardized exam. }\end{array}$ & $\begin{array}{l}\text { All participants passed the } \\
\text { NCLEX-RN }\end{array}$ \\
\hline $\begin{array}{l}\text { Rebeschi and } \\
\text { Aronson } 2009\end{array}$ & $\mathrm{~N}=73$ students & Descriptive study & $\begin{array}{c}\text { Capstone course ( } 2 \text { hours of seminar, } \\
\text { and } 16 \text { hours of clinical, per } \\
\text { week for } 7 \text { weeks). }\end{array}$ & $\begin{array}{l}\text { No significant improve scores } \\
\text { on achievement exams or } \\
\text { NCLEX-RN }{ }^{\circledR} \text { RN pass rates }\end{array}$ \\
\hline $\begin{array}{l}\text { Sifford and McDaniel, } \\
2007\end{array}$ & $\mathrm{~N}=47$ students & Descriptive study & $\begin{array}{l}\text { Didactic course that addressed } \\
\text { test-taking strategies, test anxiety, } \\
\text { and time management. }\end{array}$ & $\begin{array}{l}\text { The course increased scores on } \\
\text { an exit exam. A significant } \\
\text { difference was observed, } \\
\mathrm{t}(46)=-5.228, \mathrm{p}<0.001\end{array}$ \\
\hline $\begin{array}{l}\text { Sutherland, Hamilton } \\
\text { and Goodman, } 2007\end{array}$ & $\begin{array}{c}\mathrm{N}=64 \text { at-risk minority } \\
\text { students } \\
\mathrm{N}=265 \text { non-at-risk } \\
\text { minority students }\end{array}$ & Descriptive study & $\begin{array}{l}\text { Capstone course and mentoring, } \\
\text { advising tutoring and } \\
\text { educational seminars. }\end{array}$ & $\begin{array}{l}\text { Positively affected graduation } \\
\text { rates, significantly affected } \\
\text { grades, and eliminated the effects } \\
\text { of ethnicity on NCLEX-RN }{ }^{\circledR} \\
\text { success }\end{array}$ \\
\hline
\end{tabular}


NCLEX-RN ${ }^{\circledR}$ pass rate for the sample was $87.8 \%$. This represents an $8.5 \%$ increase from the past 5 -year mean pass rate of graduates from previous curriculum [39]. Student cohort scores on the NCLEX-RN ${ }^{\circledR}$ were compared before and after the implementation of a progresssion policy which set exam benchmarks and allowed for remediation and retesting [40]. Frith, Sewell and Clark (2005) described the curriculum change to computerized testing and the introduction of test preparation intervenetions [41]. After the implementation of these activities the NCLEX-RN ${ }^{\circledR}$ pass rate increased from $73 \%$ to $90 \%$. In 2009, Heroff described the changes in the curriculum of one school that included a progression policy and standardized assessments [42]. After implementation, the NCLEX-RN ${ }^{\circledR}$ pass rate increased for $78 \%$ to $93 \%$ in one year. The outcome of a quantitative case study of curriculum improvement program, which included a comprehensive exit examination, showed no statistically significant difference in the performance of students in the old versus new nursing programs [43]. Changes in instructional methods and grading policies were instituted at one school [44]. This school's program included new strategies for improvement, which included standardized testing with a progression policy and a remediation program [44]. The cumulative effect was an increase in the NCLEX-RN ${ }^{\circledR}$ pass rate from $84.1 \%$ to $95.1 \%$ [44]. Wray, Whitehead, Setter and Treas (2006) reported the results of a hospital orientation program for graduate nurses, which include preparation for NCLEX-RN ${ }^{\circledR}$ [51]. The program included a standardized comprehensive examination to predict NCLEX-RN ${ }^{\circledR}$ success. From the results of the exam, those at-risk were provided a remediation program. The students who were surveyed in the study reported that the exam results affected their study habits. As a result of the study plans, the students thought that they were more likely to pass the NCLEX-RN ${ }^{\circledR}$ [51]. The overall findings from these studies provide descriptions of curriculum changes that use standardized testing along with other interventions including progression policies. Even though most of the studies did find an increase in NCLEX-RN ${ }^{\circledR}$ pass rate after the intervention, the findings are limited to the individual programs. Identification of which intervention attributed to the increase in the pass rates was not possible as the studies did not measure for individual outcome results.

\subsection{Review Course Interventional Studies}

Seven studies investigated the outcomes of review courses aimed at improving NCLEX-RN ${ }^{\circledR}$ pass rates. Six of these courses took place in the senior year. Each course was unique in length of time, content, and teaching strategies. The purpose of one study was to compare the performance of senior nursing students on an exit exam before and after a didactic course that addressed test-taking strategies such as test anxiety, and time management [49]. The specific aim of another investigation was to assess the effectiveness of a capstone course, which included 2 hours of didactic, and 16 hours of clinical experience per week for 7 weeks [48]. A capstone course used in another study was studied along with faculty-related interventions that included mentoring, advising, and tutoring [50]. Critical thinking skills and problem-based learning were the focus of an investigation [46]. In 2008, McGann and Thompson published a report of their study investigating the factors related to academic success [47]. Their study findings suggested that mentoring by faculty can contribute to success on the NCLEX-RN ${ }^{\mathbb{B}}$ [47].

\section{DISCUSSION}

The synthesis of the latest scientific evidence is a foundation that can move the profession from where it is to the next steps in the research hierarchy. Nurse educators rely on the use of standardized testing and review courses for NCLEX-RN ${ }^{\circledR}$ success. The standardized comprehensive examinations were the primary type of testing that is being used. The use of progression policies and benchmarking have been found to add to the successful integration of standardized testing as an intervention for NCLEX-RN ${ }^{\circledR}$ success. When and how many times a student takes an examination is being researched. The review courses' content, structure, and length of time varied widely. The one similarity found in this review of the literature was that most of these activeties were focused on the last semester in the students' education. Until nurse educators have a clearer understanding of remediation, systematic development of evidencebased remediation interventions will be limited. This lack of clarity has led to a slow scientific progression towards evidence-based remediation interventions that will promote NCLEX-RN ${ }^{\circledR}$ success, but the nursing profession is beginning to build on the evidence.

\section{FUTURE DIRECTION OF NURSING EDUCATION RESEARCH}

Evidence-based practices are critical in determining effective educational strategies. It is time for nursing to acquire stronger evidence of interventional strategies that improve NCLEX-RN ${ }^{\circledR}$ pass rates. The acquisition of this new knowledge can be obtained through more rigorous research methods. Both quantitative and qualitative studies are needed. Regardless of philosophic and methodological differences, nurse educators share the same overall goals and face many of the same challenges. The use of multiple methods available within paradigms provides nursing with different methods that can provide a wealth of knowledge. Yet, a need exists for creating 
broader samples and consistent strategies so that evidence is strengthened. Nurse educators have examined multiple methods, tools and strategies that have been used in combination to increase NCLEX-RN ${ }^{\circledR}$ pass rates. A meta analysis of these interventions would not be possible because of the various multiple interventions that were implemented. Success on the NCLEX-RN ${ }^{\circledR}$ is a national issue and a move from small localized research designed to solve the problem at individual schools is a way to begin to develop a foundation of scientific evidence. It is time to expand collaboration between schools of nursing to conduct multisite studies to address this issue comprehensively. If the profession is to build on the evidence, we must strengthen the ways in which we define, create and document the interventions to promote NCLEX success.

\section{REFERENCES}

[1] Burns, N. and Grove, S.K. (2007) Understanding nursing research-Building an evidence-based practice. 4th Edition, Saunders Elsevier, St. Louis.

[2] McDowell, B.M. (2008) KATTS: A framework for maximizing NCLEX-RN performance. Journal of Nursing Education, 47, 183-186. doi:10.3928/01484834-20080401-04

[3] Greenspan, V.C., Springer, P. and Ray, K. (2009) A trinodal model for NCLEX-RN success. Nurse Educator, 34, 101-102. doi:10.1097/NNE.0b013e3181a02722

[4] Sitzman, K. (2007) Diversity and the NCLEX-RN: A double-loop approach. Journal of Transcultural Nursing, 18, 271-276. doi: $10.1177 / 1043659607301302$

[5] Culleiton, A.L. (2009) Remediation: A closer look in an educational context. Teaching \& Learning in Nursing, 4, 22-27. doi:10.1016/j.teln.2008.07.001

[6] Cunningham, H. Stacciarini, J.M.R. and Towle, S. (2004) Strategies to promote success on the NCLEX-RN for students with English as a second language. Nurse Educator, 29, 15-19. doi:10.1097/00006223-200401000-00006

[7] Stewart, S. and Dempsey, L.F. (2005) A longitudinal study of baccalaureate nursing students' critical thinking dispositions. Journal of Nursing Education, 44, 81-84.

[8] McQueen, L., Shelton, P. and Zimmerman, L. (2004) A collective community approach to preparing nursing students for the NCLEX-RN examination. Official Journal of the Association of Black Nursing Faculty in Higher Education, 15, 55.

[9] Cramer, C. and Davidhizar, R. (2008) Helping at-risk nursing students succeed on the national council licensure examination-registered nurse. Health Care Manager, 27, 269-276.

[10] Herrman, J.W. and Johnson, A.N. (2009) From beta-blockers to boot camp; preparing students for the NCLEX-RN. Nursing Education Perspectives, 30, 384-388.

[11] Poorman, S.G., Mastorovich, M.L., Liberto, T.L. and Gerwick, M. (2010) A cognitive behavioral course for at-risk senior nursing students preparing to take the NCLEX.
Nurse Educator, 35, 172-175. doi:10.1097/NNE.0b013e3181e3393f

[12] Sayles, S. and Shelton, D. (2005) Student success strategies. Official Journal of the Association of Black Nursing Faculty in Higher Education, 16, 98-101.

[13] Davenport, N.C. (2007) A comprehensive approach to NCLEX-RN ${ }^{\circledR}$ success. Nursing Education Perspectives, 28, 30-33.

[14] Sewell, J., Culpa-Bondal, F. and Colvin, M. (2008) Nursing program assessment and evaluation: Evidence-based decision making improves outcomes. Nurse Educator, 33, 109-112. doi:10.1097/01.NNE.0000312176.67529.c6

[15] Jones, J.H. and Bremner, M.N. (2008) Essential steps in implementing a comprehensive testing and review program. Nurse Educator, 33, 206-209. doi:10.1097/01.NNE.0000312219.52214.3c

[16] Holstein, B.L., Zangrilli, B.F. and Taboas, P. (2006) Standardized testing tools to support quality educational outcomes. Quality Management in Health Care, 15, 300-308.

[17] Richards, E.A. and Stone, C.L. (2008) Student evaluation of a standardized comprehensive testing program. Nursing Education Perspectives, 29, 363-365.

[18] DiBartolo, M.C. and Seldomridge, L.A. (2005) A review of intervention studies to promote NCLEX-RN success of baccalaureate students. Nurse Educator, 30, 166-171. doi:10.1097/00006223-200507000-00009

[19] Pennington, T.D. and Spurlock, D. (2010) A systematic review of the effectiveness of remediation interventions to improve NCLEX-RN pass rates. Journal of Nursing Education, 49, 485-492. doi:10.3928/01484834-20100630-05

[20] Ukpabi, C.V. (2008) Predictors of successful nursing education outcomes: A study of the north carolina central university's nursing program. Educational Research Quarterly, 32, 30-40.

[21] Adamson, C. and Britt, R. (2009) Repeat testing with the HESI exit exam-Sixth validity study. CIN: Computers, Informatics, Nursing, 27, 393-397.

[22] Spurlock, D.R. and Hunt, L.A. (2008) A study of the usefulness of the HESI exit exam in predicting NCLEXRN failure. Journal of Nursing Education, 47, 157-166.

[23] Gilmore, M. (2008) Predictors of success in associate degree nursing programs. Teaching \& Learning in Nursing, 4, 121-124. doi:10.1016/j.teln.2008.04.004

[24] Harding, M. (2010) Usefulness of a midcurricular examination for identifying at-risk nursing students. CIN: Computers, Informatics, Nursing, 28, 178-182.

[25] Yoho, M. (2007) The predictive accuracy of health education systems, Inc., examinations for associate degree nursing students. Teaching and Learning in Nursing, 2, 80-84. doi:10.1016/j.teln.2007.04.004

[26] Smith, S.P. (2005) HESI exams: Evidence-based research for predicting NCLEX success and benchmarking student progress. CIN: Computers, Informatics, Nursing, 23, S8.

[27] Uyehara, J., Magnussen, L., Itano, J. and Zhang, S.Q. (2007) Facilitating program and NCLEX-RN success in a generic BSN program. Nursing Forum, 42, 31-38. doi:10.1111/j.1744-6198.2007.00063.x 
[28] Tipton, P., Pulliam, M., Beckworth, C., Illich, P., Griffin, R. and Tibbitt, A. (2008) Predictors of associate degree nursing students' success students. Southern Online Journal of Nursing Research, $\mathbf{8}, 8$.

[29] Haas, R.E., Nugent, K.E. and Rule, R.A. (2004) The use of discriminant function analysis to predict student success on the NCLEX-RN. Journal of Nursing Education, 43, 440-446

[30] Seldomridge, L.A. and DiBartolo, M.C. (2005) A profile of accelerated second bachelor's degree nursing students. Nurse Educator, 30, 65-68. doi:10.1097/00006223-200503000-00007

[31] Shirrell, D. (2008) Critical thinking as a predictor of success in an associate degree nursing program. Teaching \& Learning in Nursing, 3, 131-136. doi:10.1016/j.teln.2008.05.001

[32] Giddens, J. and Gloeckner, G.W. (2005) The relationship of critical thinking to performance on the NCLEX-RN. Journal of Nursing Education, 44, 85-89.

[33] Crow, C.S., Handley, M., Morrison, R.S. and Shelton, M.M. (2004) Requirements and interventions used by bsn programs to promote and predict NCLEX-RN success: A national study. Journal of Professional Nursing, 20, 174186. doi:10.1016/j.profnurs.2004.04.004

[34] Higgins, B. (2005) Strategies for lowering attrition rates and raising NCLEX-RN pass rates. Journal of Nursing Education, 44, 541-547.

[35] Woo, A., Wendt, A. and Liu, W. (2009) NCLEX-RN pass rates: An investigation into the effect of lag time and retake attempts. JONA's Healthcare Law, Ethics \& Regulation, 11, 23-26. doi:10.1097/NHL.0b013e31819a78ce

[36] Griffiths, M.J., Papastrat, K., Czekanski, K. and Hagan, K. (2004) The lived experience of NCLEX failure. Journal of Nursing Education, 43, 322-325.

[37] Rogers, T.L. (2010) Prescription for success in an associate degree nursing program. Journal of Nursing Education, 49, 96-100. doi:10.3928/01484834-20091022-03

[38] Choe, K. and Yang, B. (2009) Korean nurses' experience of preparing for and taking the national council licensure examination for registered nurses. Asian Nursing Research, 3, 177-185.

[39] Bondmass, M.D., Moonie, S. and Kowalski, S. (2008) Comparing net and eri standardized exam scores between baccalaureate graduates who pass or fail the NCLEX$\mathrm{RN}^{\circledR}$. International Journal of Nursing Education Scholarship, 5, 16.
[40] Bonis, S., Taft, L. and Wendler, M.C. (2007) Strategies to promote success on the NCLEX-RN: An evidence-based approach using the ace star model of knowledge transformation. Nursing Education Perspectives, 28, 82-87.

[41] Frith, K.H., Sewell, J.P. and Clark, D.J. (2006) Best practices in NCLEX-RN readiness preparation for baccalaureate student success. Computers, Informatics, Nursing \& Nurse Educator, 24, 46S-53S.

[42] Heroff, K. (2009) Guidelines for a progression and remediation policy using standardized tests to prepare associate degree nursing students for the NCLEX-RN at a rural community college. Teaching and Learning in Nursing, 4, 79-86.

[43] Morris, T. and Hancock, D.R. (2008) Program exit examinations in nursing education: Using a value added assessment as a measure of the impact of a new curriculum. Educational Research Quarterly, 32, 19-29.

[44] Norton, C.K., Relf, M.V., Cox, C.W., Farley, J., Lachat, M., Tucker, M. and Murray, J. (2006) Ensuring NCLEXRN success for first-time test-takers. Journal of Professional Nursing, 22, 322-326.

[45] Wray, K., Whitehead, T., Setter, R. and Treas, L. (2006) Use of NCLEX-RN preparation strategies in a hospital orientation program for graduate nurses. Nursing Administration Quarterly, 30, 162-177.

[46] Lyons, E.M. (2008) Examining the effects of problembased learning and NCLEX-RN scores on the critical thinking skills of associate degree nursing students in a southeastern community college. International Journal of Nursing Education Scholarship, 5, 1-17. doi:10.2202/1548-923X.1524

[47] McGann, E. and Thompson, J.M. (2008) Factors related to academic success in at-risk senior nursing students. International Journal of Nursing Education Scholarship, 5, 1-15. doi:10.2202/1548-923X.1465

[48] Rebeschi, L. and Aronson, B. (2009) Assessment of nursing students learning outcomes and employment choice after the implementation of a senior capstone course. International Journal of Nursing Education Scholarship, 6, 1-5.

[49] Sifford, S. and McDaniel, D.M. (2007) Results of a remediation program for students at risk for failure on the NCLEX-RN exam. Nursing Education Perspectives, 28, 34-36.

[50] Sutherland, J.A., Hamilton, M.J. and Goodman, N. (2007) Affirming at-risk minorities for success (ARMS): Retention, graduation, and success on the NCLEX-RN. Journal of Nursing Education, 46, 347-353. 